\title{
Openness and government size: The compensation and efficiency hypotheses considered for Nigeria
}

\author{
Kolawole Opeyemi OLAWOLE ${ }^{1 *}$ and Temidayo Oyeyemi ADEBAYO ${ }^{1}$ \\ ${ }^{1}$ Department of Economics, Obafemi Awolowo University, Ile-lfe, Nigeria
}

Accepted 15 December, 2017

This paper investigates the relationship among financial openness, trade openness and government size in Nigeria. The study employed the autoregressive distributed lag (ARDL) approach to cointegration to investigate the relationship among the variables. Empirical estimates revealed that financial openness is significantly and negatively related to government size in line with the conventional wisdom that capital mobility may undermine the ability of governments to tax and raise revenue to finance government expenditure which is termed as the efficiency hypothesis. In addition, a positive relationship was reported between trade openness and government size which implies that there is evidence to support compensation hypothesis. The findings of the study suggest that openness has made the country highly vulnerable to external risk and there is need for the government to increase government expenditure and most especially, devote more funds to social welfare expenditure. This will help cushion the negative effects openness and its associated risks has on the country's citizens.

Keywords: Openness, Government Size, External Risk

JEL classification: F15, F41, H50,

\section{INTRODUCTION}

One of the major issues that have dominated policy making in countries all over the world is the need to remove restrictions to trade and cross border financial transactions. The attention these has received is based on the conventional wisdom that trade is good for growth and unrestricted capital inflows can help put a country on a more sustainable path to economic growth and development. As evident over the last three decades, most reform policies in countries, especially developing countries have been targeted at financial and trade openness. Another major issue that has been receiving attention in recent times is the trend of more open economies having a larger government size. The explanation for this is that increasing degree of openness

\footnotetext{
${ }^{*}$ Corresponding Author Email: kholarr ola@yahoo.com
}

means more exposure to external risk, as such, a larger public sector will be demanded to compensate for external risk and for the increased level of inequality associated with openness. These in turn results in larger demands for government transfers (social security, pensions, unemployment insurance) which mitigate external risk.

In Nigeria, the path towards openness started with the introduction of the Structural Adjustment Programme (SAP) in 1986. Before this time, Nigeria had a repressed financial system where the government and the Central Bank of Nigeria (CBN) restricted and controlled the activities of the financial sector. Interest rates were generally fixed by the Central Bank of Nigeria with periodic adjustments depending on the government's sectoral priorities (Agu, 1988; Uchendu, 1993). With the implementation of the SAP, several measures were taken to reduce government control of the financial system. The steps that were taken in this regard were interest rate 
deregulation, introduction of an auction market for treasury bills, identification of insolvent banks for restructuring, capital account liberalization, introduction of more stringent prudential guidelines for banks, increase in banks' minimum capital requirement and upgrading and standardizing of accounting procedures (Agu et al., 2014; Orji et al., 2014). Apart from the financial sector reforms, several policy measures were also targeted at trade liberalization. Prior to 1986, Nigeria's trade policy was premised on import substitution strategy while from 1986, the country adopted the export promotion strategy. Other important changes that took place after 1986 also include the introduction of various types of the floating exchange rate regime and the implementation of a broad based and a comprehensive tariff system. These policy measures have over the years led to the increasing importance of trade as a key driver of economic activities in the country. The broad measure of trade openness, trade to GDP increased from $23.7 \%$ in 1986 to $41.6 \%$ in 1987 and further to $53 \%$ in 1990 . By 1995 , it had risen to $59.7 \%$ and in 3 1999, it was 59.8\%. Between 2000 and 2015, trade to GDP ratio averaged 52.8\% (WDI, 2015). Furthermore, foreign direct investment (FDI) flow into the country increased from an average of $1.3 \%$ GDP (preliberalization) to an average of $2.6 \%$ of GDP after liberalization (WDI, 2015). In addition, the size of the public sector in Nigeria has increased considerably in the last three decades. Government size (measured by government expenditure as a ratio of GDP) averaged $8.7 \%$ between 1986 and 2015 with a minimum of $4.8 \%$ in 1991 and a maximum of $17.9 \%$ in 1994 (WDI, 2015).

The relationship between openness and government size was first documented by Cameron (1978). In the study, it is argued that trade openness increases an economy's exposure to the international economy and its associated risks, which in turn results in larger public expenditure to compensate for external risk. The argument that government size helps to insulate an economy against external risk was also investigated by Rodrik (1998) and empirical result reported a positive relationship between trade openness and government size. This result also conforms to the empirical evidence provided by Aydogus and Topcu (2013), Lin et al. (2014) and Tash et al. (2017).

Most of this debate has however focused on one aspect of openness (trade openness). In recent times, it has been argued that financial openness may play a role in shaping government size. This is based on the argument that increasing degrees of financial openness may lead to higher mobility of tax factors and leave governments with a reduced ability to maintain larger public sectors. As argued by Liberati (2007), it is highly important that the net effect of the two opposing forces associated with the effect of openness on government size is determined. First, there is the compensation hypothesis which posits that trade openness leads to an increase in external exposure and larger public expenditure to compensate for increasing external risk. On other hand, there is an alternative argument which opines that higher financial openness would make it harder to tax and to issue public debt to finance public expenditures as capital may easily move abroad which is termed as the efficiency hypothesis (Liberati, 2007). So, if the ability of government to tax and raise revenue is constrained, it remains to be seen, how openness can actually stimulate an increase in the size of government.

The studies by Iversen and Cusack (2000) and Liberati (2007) found support for the efficiency hypothesis while there was hardly any evidence in support of the compensation hypothesis. On the contrary, Bretschger and Hettich (2002) provided evidence in support of the compensation hypothesis while the efficiency hypothesis was rejected. Also, very few attempts have been made to establish the compensation and efficiency hypotheses in Nigeria. The studies by Aregbeyen and Ibrahim (2014) and Nwaka and Onifade (2015) investigated the relationship between trade openness and government size and found strong evidence in support of the compensation hypothesis, but these studies did not consider financial openness. In line with the arguments that financial openness may undermine the validity of the compensation hypothesis, the results obtained by these studies may not be valid. In addition, these studies did not provide any evidence on the relationship between financial openness and government size. To put this study in the right perspective, it is important to carry out a review of the existing empirical literature.

\section{Literature review}

In a pioneering paper on the expansion of the public economy, Cameron (1978) found a positive association between trade openness and the size of the public sector for a sample of 18 OECD countries. His explanation was a mixture of economic, sociological and political characteristics, where the degree of industrial concentration, the density of unionization, the scope of collective bargaining and the strength of labour confederations played the most prominent role. This result was also supported by Rodrik (1998). Ibid reestablished the positive association between trade openness and the size of the public sector, extending empirical evidence to more than a hundred countries among developed and developing countries. More recently, Sanz and Velázquez (2003) have investigated the effects of the openness of the economy, including the averaged stock of inward and outward foreign direct investments as a proxy for financial openness. Their main finding is that openness is positively associated with the share of health and social security expenditures in total government expenditures and negatively related to 
education, housing, transport and communication shares of public expenditures.

Studies by Bretschger and Hettich (2002) provide evidence that both financial openness and trade openness may positively affect the level of social welfare expenditures. The importance of financial openness for social welfare effort, has also been recently investigated by Swank (2002), with no evidence that it has had any effect while Garena and Trask (2005) show that less open countries may have higher public sectors as measured by non-budgetary indicators. Kocatepe and Nevsehir (2013) examined also the linkage between trade openness and the size of the government in Turkey over the period 1974-2011. Using residual based cointegration approach, the study found no evidence to support the compensation hypothesis. In the study of Shahbaz et al. (2010) which explored the impact of trade and financial openness on government size in the case of Pakistan using the FMOLS for cointegration and NgPerron for unit root estimation along with ECM for short run dynamics. Empirical results found that tradeopenness is associated positively with the size of government in Pakistan while financial openness 41 and government size are allied inversely, thus, confirming the validity of the compensation and efficiency hypotheses.

In the study by Kimakova (2009), both trade and financial openness were associated with a larger government size, thus, providing evidence in support of the compensation hypothesis, but rejecting the validity of the efficiency hypothesis while on the contrary, the study by Katumba (2013), found that both trade and financial openness were negatively and significantly related to government size giving credence to the validity of the efficiency hypothesis but rejecting the validity of the compensation hypothesis which is also in line with the findings by Liberati (2007), Bennaroch and Pandey (2012) and Dixit (2014). On the contrary, In Nigeria, very few studies have been carried out in this area, the study by Aregbeyen and Ibrahim (2014) investigated the subject matter using the bounds testing approach to cointegration within an ARDL framework. Empirical results reported that government size measured by percentage share of total government expenditure in GDP and share of recurrent expenditure in GDP significantly affects trade openness in the long run but percentage share of capital expenditure in GDP as a measure of government size does not impact on trade openness in the long run. This conforms to the empirical results obtained by Nwaka and Onifade (2015).

The survey of the literature highlights two major shortcomings of existing studies. First, most of the existing studies focused on one dimension of openness, namely trade openness which is not justified on empirical grounds since more reforms in developing countries, particularly Nigeria have been targeted at financial openness. Also, there have been controversies on the validity or otherwise of the compensation and efficiency hypotheses. Available studies on Nigeria found evidence in support of the compensation hypothesis, but these studies did not account for financial openness which may affect the validity of their results. In addition, there is little or no empirical evidence on the relationship between financial openness and government size. The failure to account for financial openness means that the compensation hypothesis may not hold in the case of Nigeria, since the mobility of capital may impede the ability of government to tax and raise revenue; hence this study.

\section{DATA AND METHODOLOGY}

\section{Data and empirical modeling}

The data used in the study covers annual time series data from 1986 to 2015. Data on government size, trade openness and economic growth were sourced from World Development Indicators (WDI) while data on financial openness was sourced from the Lane and Milesi-Feretti dataset. Following Liberati (2007), Kimakova (2009), Bennaroch and Pandey (2012) and Dixit (2014, the general form of our empirical specification is expressed as follows:

$$
G S_{t}=f\left(F O_{t}, T O_{t}, P C G D P_{t}\right)
$$

The linear model describing the relationship between openness and government size is specified in econometric form as:

$$
G S_{t}=\beta_{0}+\beta_{1} F O_{t}+\beta_{2} T O_{t}+\beta_{3} P C G D P_{t}+\varepsilon_{t}
$$

Where GS is government size, FO measures financial openness, TO is trade openness, PCGDP is economic growth, $\varepsilon$ is the error term and $t$ is time period. Financial openness, trade openness and government size are measured as a percentage of GDP (\% of GDP) while economic growth is measured in US\$ dollars. In line with the conventional wisdom that rising income levels can also determine government size, we introduced per capita GDP to represent the level of economic growth. This variable is expected to have a positive influence on government size, as proposed by Adolph Wagner. In addition, this study expects a positive relationship between trade openness and government size and a negative relationship between financial openness and government size. This would imply that the compensation and efficiency hypotheses holds for the case of Nigeria.

\section{Unit root test}

The first step in empirical analysis is to test the stationary properties of the variables. To carry out this test, we used the Augmented Dickey-Fuller (ADF) and Phillips-Perron 
approaches. The Augmented Dickey Fuller approach accounts for the autocorrelation of the first differences of a series in a parametric fashion by estimating additional nuisance parameters while the Phillips-Perron unit root test makes use of non-parametric statistical methods to take care of the serial correlation in the error terms without adding lagged difference terms (Gujarati and Porter, 2009).

\section{The ARDL bounds testing}

This study employs the autoregressive distributed lag (ARDL) technique by Pesaran et al. (2001) to examine the relationship between openness and government size. The main advantage of this technique lies in the fact that it can be applied irrespective of whether the variables are $\mathrm{I}(0)$ or I(1). In comparison with other known cointegration methods, the ARDL approach allows different optimal lags for the variables, and is a very useful tool since it substantially improves the small-sample properties of the estimates regardless of the nature of the time series, stationary or not.

The ARDL model is specified as:

$$
\begin{gathered}
\Delta G S_{t}=\alpha_{0}+\sum_{j=1}^{p} \vartheta_{j} \Delta G S_{t-j}+\sum_{j=0}^{a} \delta_{j} \Delta F O_{t-j}+\sum_{j=0}^{b} \phi_{j} \Delta T O_{t-j}+\sum_{j=0}^{c} \gamma_{j} \Delta \ln P C G D P_{t-j} \\
+\beta_{1} G S_{t-1}+\beta_{2} F O_{t-1}+\beta_{3} T O_{t-1}+\beta_{4} \ln P C G D P_{t-1}+\mu_{t}
\end{gathered}
$$

Thus, reparameterizing the equation above to obtain short-run coefficients by estimating error-correction model associated with long-run estimation, the model is specified as follows:

$$
\begin{gathered}
\Delta G S_{t}=\alpha_{0}+\sum_{j=1}^{p} \vartheta_{j} \Delta G S_{t-j}+\sum_{j=0}^{a} \delta_{j} \Delta F O_{t-j}+\sum_{j=0}^{b} \phi_{j} \Delta T O_{t-j}+\sum_{j=0}^{c} \gamma_{j} \Delta \ln P C G D P_{t-j} \\
+\psi E C M_{t-1}+\mu_{t}
\end{gathered}
$$

$\Delta$ denotes the first difference operator, $\alpha_{0}$ is the drift component, $p$ is the lag length which will be chosen using lag selection criterion and $\mu_{t}$ is the error term. The coefficients $\left(\vartheta_{j}, \delta_{j}, \phi_{j}, \gamma_{j}\right)$ represents the short run effects while the coefficient $\psi$ associated with ECM allows for adjustment back to the long-run equilibrium. Also, it is assumed that the variables used in the study are at most integrated of order one 1(1), that is, the variables are at most stationary at first difference.

\section{EMPIRICAL RESULTS}

The result of the descriptive statistics is presented in Table 1. The table shows that all the variables display a high level of consistency as their mean and median values have values within the minimum and maximum values. The standard deviation which indicates the dispersions of the actual data from their mean reported low standard deviation for most of the series. Presented in Table 2 is the result of the unit root tests obtained using Augmented Dickey Fuller (ADF) and Phillips Perron (PP) both at level and at first difference. From Table 2, it is observed that government size is stationary at level while other variables became stationary at first difference. Thus, since there is a combination of $\mathrm{I}(0)$ and $\mathrm{I}(1)$ variables, the Autoregressive Distributed Lag (ARDL) technique becomes an appropriate analytical tool. To test the validity or otherwise of the compensation and efficiency hypotheses, this study examined the effect of openness (financial and trade openness) on government size using the Autoregressive Distributed Lag (ARDL) estimation technique. The selection of the lag length for this study is based on the outcome of Akaike Information Criterion (AIC) as presented in Table 3 due to its small properties. Based on the outcome of the Akaike Information Criterion, lag length 2 is chosen for this study.

The result of the bound test reported in Table 4 reveal that our computed F-statistic (6.63) fell above the upper critical bound at $1 \%$ level of significance (5.61). This validates that there is long run relationship between openness and government size. With the confirmation of long-run relationship between openness and government size, the study can then proceed to test the validity of the compensation and efficiency hypotheses. Having established that there is long run relationship between openness and government size, the next step is to examine long run effect of openness on government size. The results detailed in Table 5 reveal that financial openness has a negative effect on government size at $1 \%$ level of significance. This validates the existence of the efficiency hypothesis, that is, financial openness is not associated with a larger government size. A $1 \%$ increase in the degree of financial openness will therefore lead to a $0.10 \%$ reduction in the size of government. This confirms the findings by Liberati (2007), Katumba (2013) and Dixit (2014). The result is however not consistent with the hypothesis that governments in financially open economies hedge against the well documented volatility of international capital flows by increasing government spending. In addition, the empirical findings also reflect the economic realities in the country. Rising inflation, exchange rate volatility and the high cost of doing business in the country has led to the exit of many multinational corporations. Also, capital inflow into the Nigerian economy has been declining in recent times. All these has led to declining government revenue and has hampered the ability of government to maintain a larger government size.

On the other hand, trade openness was found to have a positive and significant effect on government size. This confirms the validity of the compensation hypothesis in the case of Nigeria. For any $1 \%$ increase in the degree of 
Table 1: Descriptive Statistics of the Variable

\begin{tabular}{lcccc}
\hline Statistic/Variable & GS & FO & TO & PCGDP \\
\hline Mean & 8.616293 & 78.87112 & 54.22697 & 928.7902 \\
Median & 7.425769 & 55.50473 & 57.90042 & 363.8802 \\
Maximum & 17.94384 & 172.3755 & 81.81285 & 3203.244 \\
Minimum & 4.833249 & 31.51432 & 21.44693 & 153.0757 \\
Std. Dev. & 3.141211 & 45.38459 & 15.42919 & 976.1019 \\
Skewness & 1.145341 & 0.660129 & -0.44625 & 1.25869 \\
Kurtosis & 3.808796 & 2.040919 & 2.52726 & 3.023682 \\
Jarque-Bera & 7.37672 & 3.328648 & 1.275047 & 7.922203 \\
Sum & 258.4888 & 2366.134 & 1626.809 & 27863.71 \\
Sum Sq. Dev. & 286.149 & 59733.07 & 6903.735 & 27630474 \\
Observations & 30 & 30 & 30 & 30 \\
\hline
\end{tabular}

Source: Researcher's Computation. Note: GS, FO, TO and Y denotes government size (\% of GDP), financial openness (\% of GDP, trade openness (\% of GDP) and economic growth (US\$) respectively.

Table 2: Result of Unit Root Tests

\begin{tabular}{lcccccc}
\hline \multicolumn{5}{c}{ ADF } & \multicolumn{3}{c}{ PP } \\
\hline Variables & Level & First Diff. & Status & Level & First Diff. & Status \\
\hline GS & -3.3455 & & $\mathrm{I}(0)$ & -3.4016 & & $\mathrm{I}(0)$ \\
& & {$[0.0218]^{* *}$} & & {$[0.0192]^{* *}$} & & \\
FO & -1.6008 & -5.941737 & $\mathrm{I}(1)$ & -1.5253 & -5.9116 & $\mathrm{I}(1)$ \\
& {$[0.4694]$} & {$[0.0000]^{* * *}$} & & {$[0.5069]$} & {$[0.0000]^{* * *}$} \\
TO & -2.5947 & -3.851 & $\mathrm{I}(1)$ & -2.5791 & -8.0155 & $\mathrm{I}(1)$ \\
& {$[0.1055]$} & {$[0.0087]^{* * *}$} & & {$[0.1087]$} & {$[0.0000]^{* * *}$} \\
InPCGDP & 0.001 & -5.6828 & $\mathrm{I}(1)$ & 0.1856 & -5.7151 & $\mathrm{I}(1)$ \\
& {$[0.9512]$} & {$[0.0001]^{* * *}$} & & {$[0.9668]$} & {$[0.0001]^{* * *}$} \\
\hline
\end{tabular}

Source: Researcher's Computation. Note: ${ }^{* * *}$ indicates significance at $1 \%$ level and ${ }^{* *}$ indicates significance at $5 \%$. ADF is Augmented Dickey- Fuller test and PP is Phillips-Perron test.

Table 3: Lag Length Selection Criteria

\begin{tabular}{lcccccc}
\hline Lag & LogL & LR & FPE & AIC & SC & HQ \\
\hline 0 & -332.7881 & NA & 802825.8 & 24.94727 & 25.13924 & 25.00435 \\
1 & -276.8631 & 91.13706 & 42431.29 & 21.98986 & $22.94974^{*}$ & 22.27528 \\
2 & -256.6384 & $26.96622^{*}$ & $33905.50^{\star}$ & $21.67692^{*}$ & 23.4047 & $22.19068^{\star}$ \\
3 & -242.0925 & 15.08461 & 48077.04 & 21.78463 & 24.28032 & 22.52673 \\
\hline
\end{tabular}

Source: Researcher's Computation. Note: * indicates lag order selected by the criterion; LR, FPE, AIC, SIC and HQ indicate sequential modified LR test statistic, Final Prediction Error, Akaike Information Criterion, Schwarz Information Criterion and Hannan-Quinn respectively. 
Table 4: ARDL Bound Test

\begin{tabular}{lllll}
\hline F-Statistic & No of Regressors & Critical Values & $\mathbf{I}(\mathbf{0})$ & $\mathbf{I}(\mathbf{1})$ \\
\hline 6.627419 & 3 & $10 \%$ & 2.72 & 3.77 \\
& $5 \%$ & 3.23 & 4.35 \\
& $1 \%$ & 4.29 & 5.61 \\
\hline
\end{tabular}

Source: Researcher's Computation

Table 5: Long Run Regression Result (Dependent Variable: Government Size)

\begin{tabular}{lcccc}
\hline Variable & Coefficient & Std. Error & t-Statistic & Prob. \\
\hline FO & -0.097057 & 0.019300 & -5.029 & $0.0001^{* * *}$ \\
TO & 0.095456 & 0.035542 & 2.68577 & $0.0151^{* *}$ \\
InPCGDP & -26.89628 & 6.511619 & -4.1305 & $0.0006^{* * *}$ \\
\hline
\end{tabular}

Source: Researcher's Computation. Note: *** indicates significance at $1 \%$ level, ${ }^{* *}$ indicates significance at $5 \%$. and * indicates significance at $10 \%$.

Table 6: Short Run Parsimonious Regression Result (Dependent Variable: Government Size)

\begin{tabular}{lcccc}
\hline Variable & Coefficient & Std. Error & t-Statistic & Prob. \\
\hline $\mathrm{D}(\mathrm{FO})$ & -0.087866 & 0.02108 & -4.168165 & $0.0006^{\star \star *}$ \\
$\mathrm{D}(\mathrm{TO})$ & 0.086417 & 0.033793 & 2.557239 & $0.0198^{\star *}$ \\
$\mathrm{D}(\operatorname{InPCGDP})$ & -5.477708 & 1.969833 & -2.780799 & $0.0123^{* * *}$ \\
$\mathrm{D}(\operatorname{InPCGDP}(-1))$ & 4.459723 & 2.323148 & 1.919689 & $0.0709^{*}$ \\
$\mathrm{D}(\operatorname{InPCGDP}(-2))$ & 3.338745 & 1.869578 & 1.785828 & $0.0910^{*}$ \\
ECM(-1) & -0.905307 & 0.180886 & -5.004858 & $0.0001^{\star * *}$ \\
$\mathrm{R}^{2}$ & 0.684846 & & & \\
Adjusted $R^{2}$ & 0.562286 & & & \\
D-W & 2.031559 & & & \\
F-Statistic & $5.587851(0.001516)$ & & & \\
\hline
\end{tabular}

Source: Researcher's Computation. Note: ${ }^{* * *}$ indicates significance at $1 \%$ level, ${ }^{* *}$ indicates significance at $5 \%$. and ${ }^{*}$ indicates significance at $10 \%$

trade openness, government size will increase by $0.10 \%$. This result is in agreement with the empirical evidence provided by Rodrik (1998), Kimakova (2009), Aregbeyen and Ibrahim (2014) and Nwaka and Onifade (2015). Also, economic growth was found to have a negative and significant effect on government size, thus, there is no evidence to support Wagner's law in the long run. This empirical finding is supported by Bennaroch and Pandey (2012) and Dixit (2014).
Table 6 presents the short run estimates of the ARDL model. Empirical results reveal that financial openness has a negative effect on government size in the short run at $1 \%$ level of significance which is in consonance with the long run estimates. A $1 \%$ increase in the extent of financial openness will cause government size to decline by $0.09 \%$. This means that financial openness does not lead to an increases in government size and the efficiency hypothesis is also valid in the short run. On the 
Table 7: ARDL Diagnostic Tests

\begin{tabular}{lcc}
\hline Test & F-Statistics & Probability \\
\hline Serial Correlation & 0.0726 & 0.9303 \\
Functional Form & 1.4432 & 0.1624 \\
Normality & 2.2359 & 0.3269 \\
Heteroscedasticity & 1.0171 & 0.4523 \\
\hline
\end{tabular}

Source: Researcher's Computation

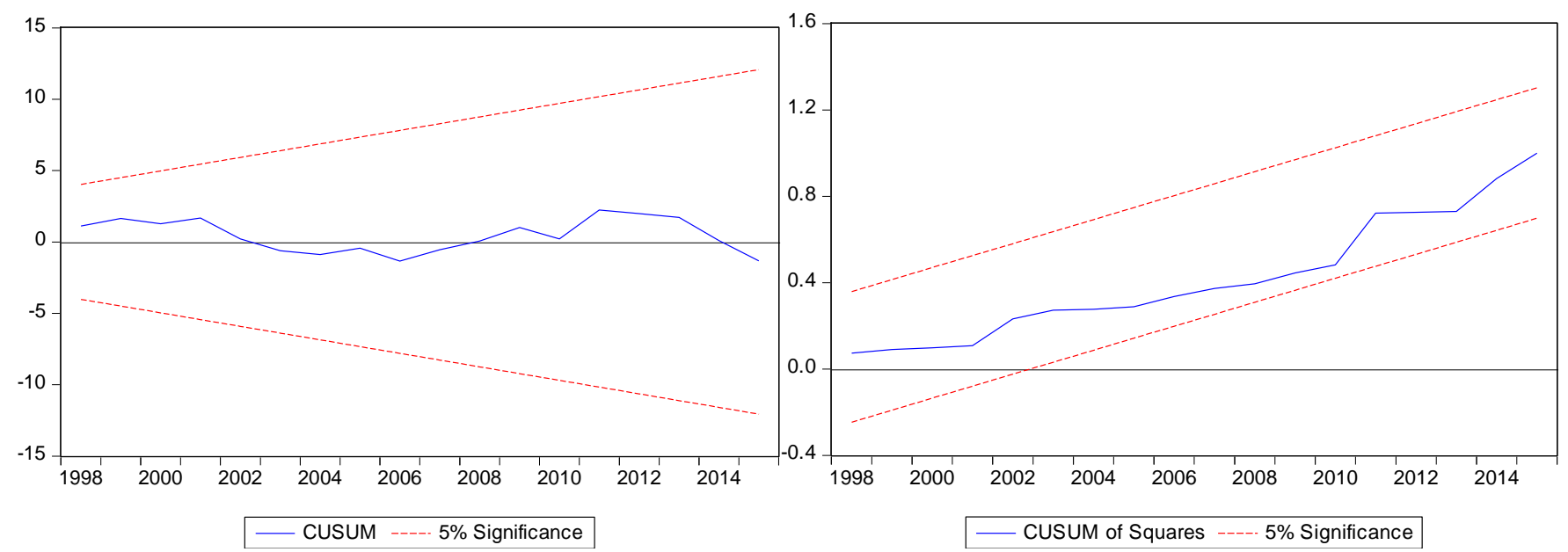

Figure 1: Cusum and Cusum of Squares Stability Tests (Source: Author's Computation, 201)

other hand, trade openness was found to have a negative and significant on effect government size in the short run which is not in line with the long run estimate, thus, rejecting the validity of the compensation hypothesis in the short run. A $1 \%$ increase in trade openness will cause government size to decline by $0.09 \%$.

Short run estimates also reveal that the current year value of economic growth had a negative effect on government size at $5 \%$ level of significance while the previous year values (at lag 1 and 2) had a positive effect on government size although it is significant at $10 \%$ level of significance. For any $1 \%$ increase in the current year value of economic growth, government size will decline by $5.48 \%$ while for any $1 \%$ increase in the previous year value of economic growth (both at lag 1 and 2), government size will increase by $4.46 \%$ and $3.33 \%$ respectively.

The value of the error correction model $(-0.905307)$ shows that $91 \%$ of disequilibrium errors are corrected. Furthermore, the $\mathrm{R}^{2}$, adjusted $\mathrm{R}^{2}$, Durbin-Watson and $\mathrm{F}$ Statistics of the short run effect of openness on government size are in the right magnitude. The short run estimates also show that the co-efficient of the $R^{2}$ is approximately $68 \%$ which implies that the explanatory variables in the model explain a higher variation in economic growth. This implies that the regression equation has a good fit because less than $32 \%$ of the total variation in economic growth is explained by the variables that are not clearly stated in the model. The adjusted $R^{2}$ which is the adjusted multiple coefficient of the determination also indicates that about $56 \%$ of the total variation in economic growth is explained by the variables in the model. The Durbin-Watson (2.03) shows that the problem of serial correlation is absent in the model. The null hypothesis which states that the estimated model does not suffer from serial correlation can be accepted since the value is approximately 2 .

The results of the ARDL diagnostic tests are presented in Table 7. The test for serial autocorrelation proved that there is absence of autocorrelation in the residuals of the ECM estimate. This is as a result of the insignificant Fstatistic. Table 7 also reveals that the model also passes all the other diagnostic tests for functional form, normality and heteroscedasticity.

The results of stability tests such as CUSUM and CUSUMsq are shown in Figure. 1. The results of CUSUM and CUSUMsq tests indicate the stability of the ARDL parameters because both diagrams are within critical bounds at 5 percent level of significance. If the plots of the CUSUM and CUSUMsq stay in the $5 \%$ critical bound, 
then the null hypothesis that all coefficients are stable cannot be rejected. Moreover, if either of the parallel lines is crossed, then the null hypothesis of parameter stability must be rejected at a $5 \%$ level of significance. The results reveal that both the CUSUM and CUSUMsq plots lie within the $5 \%$ critical bound; hence, they show that the parameters of the model do not suffer from any structural instability over the period under review.

\section{Conclusion}

This study examined the relationship between openness and government size in Nigeria with a view to determine the validity or otherwise of the compensation and efficiency hypotheses. The long run estimates revealed that financial openness had a negative effect on government while trade openness had a positive effect. This result provided support for the compensation and efficiency hypotheses in the case of Nigeria. In addition, long run estimates revealed that economic growth had a negative and significant effect on government size. For a country highly vulnerable to external risks, the implication of this result cannot be overemphasized. The country's over-reliance on crude oil whose prices are highly volatile has made the country highly susceptible to fluctuations in crude oil prices. This often translates into falling government revenue, decline in foreign exchange earnings and rising exchange rate volatility with its attendant effect on inflation and the living standard of the country's citizens. Thus, without an increasing government size to cushion these negative effects, the country's citizens will be worse off.

\section{REFERENCES}

Agu CC (1988). "Interest Rate Policy in Nigeria: An Attendant Distortion." Savings. Invest. J, 12(1)

Agu CC, Orji A, Eigbiremolen G (2014). "Financial Liberalization, Interest Rate Structure and Savings Mobilization: The Nigerian Experience" Intl. J. Current. Res. 6(1)

Aregbeyen O, Ibrahim TM (2014). "Trade Openness-Government Size Nexus: $\quad$ Compensation Hypothesis Considered for Nigeria." J. Rev. Glob. Econ. 3: 364-372.

Aydogus I, Topcu M (2013). "An Investigation of Co- Integration and Causality between Trade Openness and Government Size in Turkey", Intl. J. Econ. Financial. Issues. 3(2): 319-323.

Benarroch M, Pandey M (2008). "Trade Openness and Government Size", Econ. Lett. 101: 157-159.

Bretschger L, Hettich F (2002). "Globalisation, Capital Mobility and Tax Competition: Theory and Evidence for OECD Countries." Eur. J. Polit. Economy. 18(4): 695-716.

Cameron D (1978). "The Expansion of the Public Economy: A Comparative Analysis", Amer. Polit. Sci. Rev. 72: 1243-1261.

Central Bank of Nigeria (2015). "Statistical Bulletin." Volume 26, December, 2015.

Dickey D, Fuller WA (1979). "Distribution of the Estimates for Autoregressive Time Series with a Unit Root." J. American. Stat. Assoc. 74: 427-431.
Dixit V (2014). "Relation between Trade Openness, Capital Openness and Government Size in India: An Application of Bounds TestingARDL Approach to Co-integration." Foreign. Trade. Rev. 49(1): 1-29.

Garena J, Trask K (2005). "Do more open Economies have Bigger Governments? Another Look."J. Develop. Econ. 77(2): 533-551.

Iversen T, Cusack T (2000). "The Causes of Welfare State Expansion: Deindustrialization or Globalization?”, World Politics. 52: 313349.

Katumba OS (2013). "Globalization and Government Size: Adopting the Mean Group Estimator Model." An Unpublished M.Sc Thesis.

Kimakova A (2009). "Government Size and Openness Revisited: The Case of Financial Globalization." KYKLOS. 62(3): 394-406.

Kocatepe IA, Nevsehir MT (2013). "An Investigation of Co-Integration and Causality between Trade Openness and Government Size in Turkey." Intl. J. Econ. Financial. Issues. 3(2): 319-323.

Lane P, Milesi-Ferretti G (2017). "External Wealth of Nations Mark II Database: Revised and Extended Estimates of Foreign Assets and Liabilities, 1970-2014." J. Intl. Econ. 73: 223-50.

Lane PR, Milesi-Ferretti GM (2006). "A Global Perspective on External Positions," NBER Working, No. 11589.

Liberati P (2007). "Trade Openness, Capital Openness and Government Size. "J. Pub. Pol. 27: 215-247, doi:10.1017/S0143814X07000670.

Lin F, Li B, Sim N (2014). "Trade Openness and Government Size of Small Developing Countries." Econ. Transit. 22(4): 783-808.

Gujarati DN, Porter DC (2009). "Basic Econometrics". McGraw Hill, New York, Fifth Edition

Molana H, Montagna C, Violato M (2004). "On the Causal Relationship between Trade Openness and Government Size: Evidence from 23 OECD Countries." mimeo.

Nwaka ID, Onifade ST (2010). "Government Size, Openness and Income Risk Nexus:New Evidence from Some African Countries." African Governance Development Institute Working Paper, VI(1): $105-118$.

Orji A (2014). "Analysis of Financial Openness and Macroeconomic Performance in Nigeria". A Ph.D Thesis.

Pesaran MH, Pesaran B (1997), Working with Microfit 4.0: Interactive Econometric Analysis. Oxford, Oxford University Press.

Pesaran MH, Shin Y (1995). "Autoregressive Distributed Lag Modelling Approach to

Paper Series No. 9514.

Pesaran MH, Shin Y, Smith RJ (1996). "Testing the Existence of Long Run Relationship" DAE Working Paper Series, No. 9622.

Pesaran MH, Shin Y, Smith RJ (2001). "Bounds Testing Approaches to the Analysis of Level Relationships", J. Appl. Econom. 16(3): 289326.

Rodrik D (1998). "Why Do More Open Economies Have Bigger Governments?" J. Polit. Economy. 106: 997-1032.

Sanz I, Velzquez F (2002). "Determinants of the Composition of Government Expenditure by Functions." European Economy Group Working Paper No. 13.

Schulze G, Ursprung HW (1999). "Globalization of the Economy and the Nation State”, The World Economy. 22: 295-352.

Shahbaz M, Rehman H, Amir M (2010). "The Impact of Trade and Financial Openness on Government Size: A Case Study of Pakistan." J. Qualit. Technol.

Swank D (2002). "Global Capital, Political Institutions, and Policy Change in Developed Welfare States. Cambridge, UK: Cambridge University Press.

Tash MS, Khoramabadi T, Laghab SB (2017). "The Relationship between Government Size and Trade Openness in Iran." Intl. Bus. Manage. 11(2): 375-380.

Uchendu OA (1993). "Interest Rate Policy in Savings and Investment in Nigeria” CBN Economic. Financial. Rev. 31:13-25.

Wagner A (1893). "Groundwork of Political Economy." Grundlegung der Politschen Okonomie, Liepzig,Germany: C.F. Winter.

World Bank (2012). "World Bank Development Indicators 2012."

World Bank (2015). "World Development Indicators 2016." 


\section{APPENDIX}

1

\section{ARDL Bounds Test}

Date: 08/05/17 Time: 16:24

Sample: 19882015

Included observations: 28

Null Hypothesis: No long-run relationships exist

\begin{tabular}{lll}
\hline \hline Test Statistic & Value & $\mathrm{k}$ \\
\hline \hline F-statistic & 6.627419 & 3 \\
\hline \hline
\end{tabular}

Critical Value Bounds

\begin{tabular}{lll}
\hline \hline Significance & I0 Bound & I1 Bound \\
\hline \hline $10 \%$ & 2.72 & 3.77 \\
$5 \%$ & 3.23 & 4.35 \\
$2.5 \%$ & 3.69 & 4.89 \\
$1 \%$ & 4.29 & 5.61 \\
\hline \hline
\end{tabular}

\section{Test Equation:}

Dependent Variable: D(GS)

Method: Least Squares

Date: 08/06/17 Time: 16:14

Sample: 19882015

Included observations: 28

\begin{tabular}{lllll}
\hline \hline Variable & Coefficient & Std. Error & t-Statistic & Prob. \\
\hline \hline D(GS(-1)) & -0.217938 & 0.176595 & -1.234111 & 0.2315 \\
D(FO) & -0.084857 & 0.025973 & -3.267069 & 0.0039 \\
D(LOGPCGDP) & -6.178932 & 2.313125 & -2.671249 & 0.0147 \\
C & 7.057161 & 2.186609 & 3.227445 & 0.0042 \\
FO(-1) & -0.037773 & 0.013017 & -2.901783 & 0.0088 \\
DTO(-1) & -0.003183 & 0.036278 & -0.087725 & 0.9310 \\
DLOGPCGDP (-1) & -13.57726 & 3.743670 & -3.626725 & 0.0017 \\
GS(-1) & -0.393499 & 0.195748 & -2.010231 & 0.0581 \\
\hline \hline R-squared & 0.615571 & Mean dependent var & -0.018494 \\
Adjusted R-squared & 0.481021 & S.D. dependent var & 3.208106 \\
S.E. of regression & 2.311125 & Akaike info criterion & 4.748302 \\
Sum squared resid & 106.8260 & Schwarz criterion & 5.128932 \\
Log likelihood & -58.47623 & Hannan-Quinn criter. & 4.864665 \\
F-statistic & 4.575036 & Durbin-Watson stat & 2.027562 \\
Prob(F-statistic) & 0.003428 & & \\
\hline \hline
\end{tabular}


ARDL Cointegrating And Long Run Form

Dependent Variable: GS

Selected Model: ARDL(1, 0, 0, 3)

Date: 08/05/17 Time: 16:37

Sample: 19862015

Included observations: 27

\section{Cointegrating Form}

\begin{tabular}{lllll}
\hline \hline Variable & Coefficient & Std. Error & t-Statistic & Prob. \\
\hline \hline $\mathrm{D}(\mathrm{FO})$ & -0.087866 & 0.021080 & -4.168165 & 0.0006 \\
$\mathrm{D}(\mathrm{TO})$ & 0.086417 & 0.033793 & 2.557239 & 0.0198 \\
$\mathrm{D}($ LOGPCGDP) & -5.477708 & 1.969833 & -2.780799 & 0.0123 \\
$\mathrm{D}($ LOGPCGDP $(-1))$ & 4.459723 & 2.323148 & 1.919689 & 0.0709 \\
$\mathrm{D}($ LOGPCGDP $(-2))$ & 3.338745 & 1.869578 & 1.785828 & 0.0910 \\
CointEq(-1) & -0.905307 & 0.180886 & -5.004858 & 0.0001 \\
\hline \hline \multicolumn{2}{c}{ Cointeq = GS - (-0.0971*FO +0.0955*TO -26.8963*LOGPCGDP +12.3036) } \\
\hline \hline Long Run Coefficients \\
\hline \multirow{2}{*}{ Variable } & & & & \\
\hline \hline FO & Coefficient & Std. Error & t-Statistic & Prob. \\
TO & -0.097057 & 0.019300 & -5.028992 & 0.0001 \\
LOGPCGDP & 0.095456 & 0.035542 & 2.685772 & 0.0151 \\
C & -26.896280 & 6.511619 & -4.130505 & 0.0006 \\
\hline \hline
\end{tabular}

